\begin{tabular}{l} 
2. To: (Receiving Organization) \\
Distribution \\
\hline T. Proj./Prog./Dept./Div.: \\
Transition Project \\
\hline
\end{tabular}

8. Oríginator Remarks:

The attached document is for approval.

$$
\text { (USQ \#K-00-0577) }
$$

11. Receiver Remarks:

3. From: (Originating Organization)
Systems Engineering (2F400)
6. Design Authority/Design Agent/Cog. Engr.:
R. M. Yanochko

R. M. Yanochko \begin{tabular}{l} 
4. Related EDT No.: \\
N/A \\
7. Purchase Order No.: \\
N/A \\
\hline O. Equip /Component No:
\end{tabular}

9. Equip./Component No:

$\mathrm{N} / \mathrm{A}$

10. System/BIdg./Facility:

100 K Area Facilities

12. Major Assm. Dwg. No.:

$\mathrm{N} / \mathrm{A}$

13. Permit/Permit Application No:

$\mathrm{N} / \mathrm{A}$

14. Required Response Date:

$\mathrm{N} / \mathrm{A}$

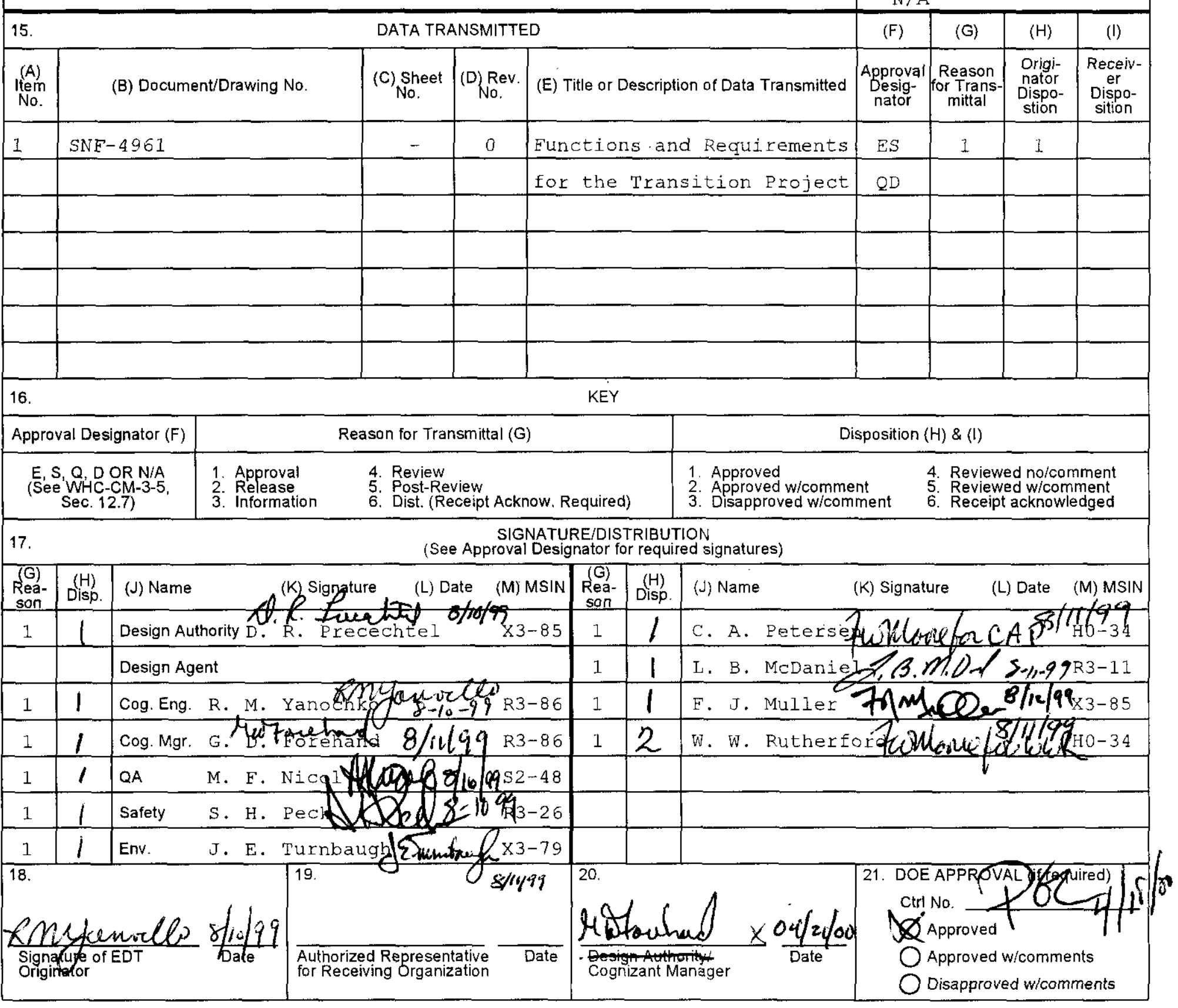


SNF-4961

Revision 0

\section{Functions and Requirements for the Transition Project}

Prepared for the U.S. Department of Energy

Assistant Secretary for Environmental Management

Project Hanford Management Contractor for the

U.S. Department of Energy under Contract DE-AC06-96RL13200

Fluor Hanford

P.O. Box 1000

Richland, Washington 
SNF-4961

Revision 0

EDT 627765

\section{Functions and Requirements for the Transition Project}

R. M. Yanochko

Fluor Hanford

Date Published

March 2000

Prepared for the U.S. Department of Energy

Assistant Secretary for Environmental Management

Project Hanford Management Contractor for the

U.S. Department of Energy under Contract DE-AC06-96RL13200

Fluor Hanford

P.O. Box 1000

Richland, Washington
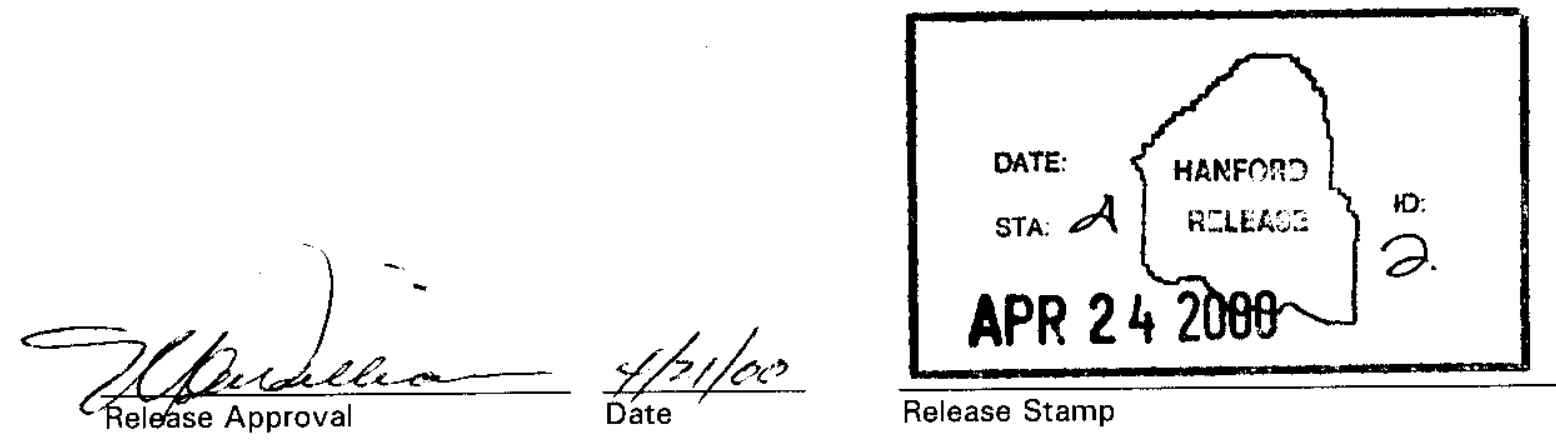

Release Stamp 
TRADEMARK DISCLAIMER

Reference herein to any specific commercial product, process, or service by trade name, trademark, manufacturer, or otherwise, does not necessarily constitute or imply its endorsement, recommendation, or favoring by the United States Government or any agency thereof or its contractors or subcontractors.

This report has been reproduced from the best available copy. Available in paper copy and microfiche.

Available electronically at http://www.doe.gov/bridge. Available for a processing fee to the U.S. Department of Energy and its contractors, in paper, from:

U.S. Department of Energy

Office of Scientific and Technical Information

P.O. Box 62

Oak Ridge, TN 37831-0062

phone: 865-576-8401

fax: 865-576-5728

email; reports@adonis.osti.gov(423) 576-8401

Printed in the United States of America

Total Pages: $\quad 39$

SNF-4961, Revo. 


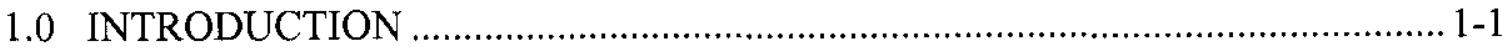

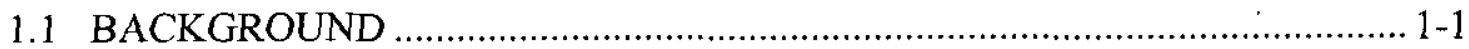

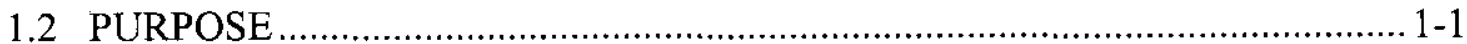

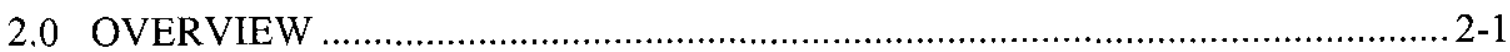

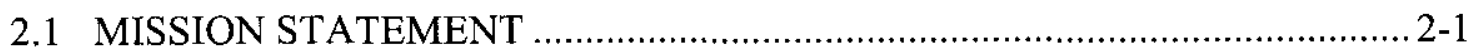

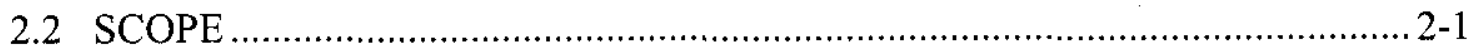

2.3 TECHNICAL BASELINE DEVELOPMENT ………................................... 2-1

2.3.1 TRANSITION PROJECT TECHNICAL BASELINE DEVELOPMENT . 2-2

2.3.2 TECHNICAL BASELINE PRODUCTS............................................. 2-2

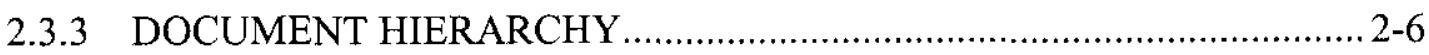

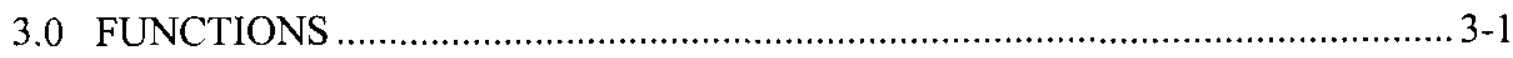

3.1 FUNCTION HIERARCHY ……………………..................................... 3-1

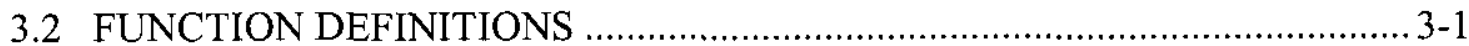

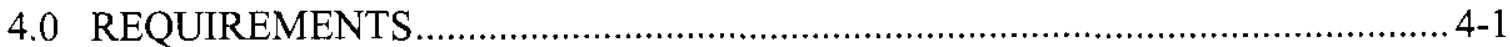

4.1 MISSION REQUIREMENTS ................................................................ 4-1

4.2 AUTHORIZATION BASIS, NEPA, AND PERMITS …………...................... 4-5

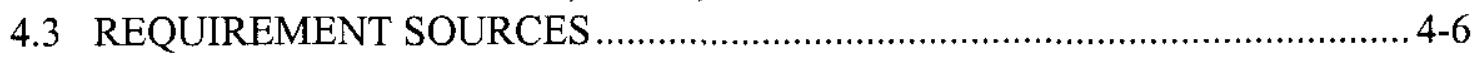

5.0 ARCHITECTURE ..................................................................................... 5-1

5.1 SPENT NUCLEAR FUEL PROJECT TRANSITION ARCHITECTURE ......... 5-1

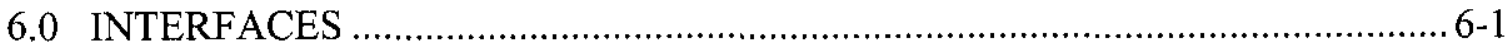

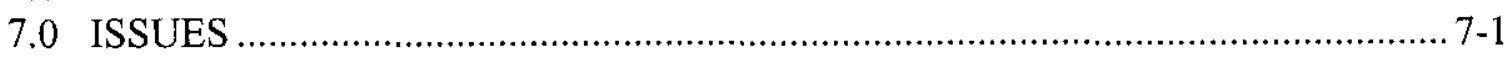

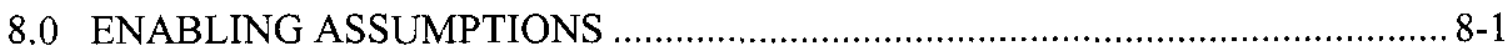

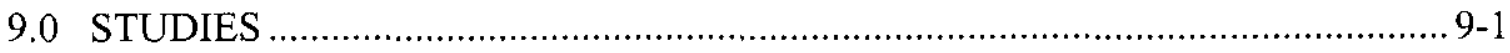

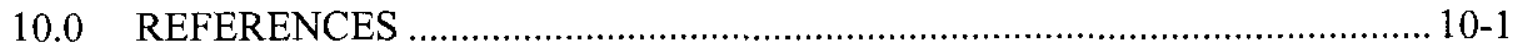

TABLE 3-1. TRANSITION FunCTION DEFINITIONS ........................................................ 3-1

TABLE 6-1. TRansition Project InTERface Description ........................................... 6-1

TABLE 7 -1. TRANSITION PROJECT ISSUES .............................................................. 7-1

Table 8-1. Transition Project Enabling AsSumptions ........................................... 8-1

Figure 2-1 Transition Project Document Tree (Sheet 1 of 3) ................................ 2-7

Figure 2-1 Transition Project Document Tree (Sheet 2 of 3) .............................. 2-8

Figure 2-1 Transition Project Document Tree (Sheet 3 of 3) ............................... 2-9

Figure 3-1. Transition Project Function Hierarchy (SheEt 1 of 2) ...................... 3-2

Figure 3-1. TRansition Project Function Hierarchy (SheET 2 of 2) ...................... 3-3

\section{List of Acronyms}

ALARA As Low As Reasonably Achievable

AP Administrative Procedure

CERCLA Comprehensive Environmental Response, Compensation and Liability Act of 1980

CVD Cold Vacuum Drying

CVI Certified Vendor Information

D\&D Decontamination and Decommissioning

DOE U.S. Department of Energy 


\begin{tabular}{|c|c|}
\hline DST & Double Shell Tank \\
\hline Ecology & U.S. Department of Ecology \\
\hline EPA & U.S. Environmental Protection Agency \\
\hline ER & Environmental Restoration \\
\hline ERDF & Environmental Restoration Disposal Facility \\
\hline $\mathrm{ES} \& \mathrm{H}$ & Environmental, Health and Safety \\
\hline ETF & Effluent Treatment Facility \\
\hline $\mathrm{F} \& \mathrm{R}$ & Functions and Requirements \\
\hline FDC & Functional Design Criteria \\
\hline FH & Fluor Hanford \\
\hline FTSB & Facilities Transition Strategy Document \\
\hline FY & Fiscal Year \\
\hline HSEMS & Hanford Site Environmental Management Specification \\
\hline HSP & Hanford Strategic Plan \\
\hline HSTD & Hanford Site Technical Database \\
\hline IWTS & Integrated Water Treatment System \\
\hline IXM & Ion Exchange Module \\
\hline $\mathrm{JCO}$ & Justification for Continued Operation \\
\hline LERF & Liquid Effluent Retention Facility \\
\hline LLW & Low-Level Waste \\
\hline MOU & Memorandum of Understanding \\
\hline MYWP & Multi-Year Work Plan \\
\hline NEPA & National Environmental Policy Act \\
\hline PDC & Packaging Design Criteria \\
\hline PEP & Project Execution Plan \\
\hline RCRA & Resource Conservation Recovery Act \\
\hline RL & U.S. Department of Energy, Richland Operations Office \\
\hline ROD & Record of Decision \\
\hline RPP & River Protection Project \\
\hline RS & Retrieval System \\
\hline S\&M & Surveillance and Maintenance \\
\hline SAR & Safety Analysis Report \\
\hline SARP & Safety Analysis Report for Packaging \\
\hline SEMP & Systems Engineering Management Plan \\
\hline SER & Safety Evaluation Report \\
\hline SNF & Spent Nuclear Fuel \\
\hline S/RID & Standards/Requirements Identification Document \\
\hline SSCs & Structures, Systems, and Components \\
\hline TPA & Tri-Party Agreement \\
\hline TRU & Transuranic \\
\hline TSD & Treatment, Storage, and Disposal \\
\hline TSR & Technical Safety Requirements \\
\hline TWRS & Tank Waste Remediation System \\
\hline USQ & Unreviewed Safety Question \\
\hline WBS & Work Breakdown Structure \\
\hline 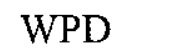 & Waste Programs Division \\
\hline
\end{tabular}




\subsection{INTRODUCTION}

This document describes the functional requirement baseline for the Transition of $100 \mathrm{~K}$ Area Facilities Project (Transition Project). This baseline information consists of top-level functions, requirements, concept description, interface description, issues, and enabling assumptions.

\subsection{BACKGROUND}

Application of systems engineering to Spent Nuclear Fuel (SNF) Project subprojects is governed by WHC-SD-SNF-SEMP-001, "SNF Project Systems Engineering Management Plan" (SEMP) (WHC 1996a).

The technical baseline information is derived from HNF-SP-1104, the "Spent Fuels Multi-Year Work Plan" (MYWP), (FDH 1998a), "Hanford Site Environmental Management Specification", DOE/RL-97-55 (DOE/RL), Contract No. DE-AC0696RL13200, Modification M071, and WHC-SD-SNF-SD-005, "Spent Nuclear Fuel Project Technical Baseline Description Fiscal Year 1996" (WHC 1996b). The technical baseline data contained herein was derived meeting the intent of procedures contained in WHC-IP-1117, "Hanford Site Systems Engineering Manual" (WHC 1995a). An SNF Project Administrative Procedure (AP) governing functions and requirement analyses is being developed at this time. Until the SNF Project AP are completed, the Hanford Site Systems Engineering Manual procedures will be utilized. Lessons learned from N Area Deactivation Project will be considered during Transition Deactivation Planning.

This technical baseline will be updated as the technical information develops throughout the Transition Project life cycle. The technical baseline development process is described in the SEMP (WHC 1996a) Section 3.3, Technical Baseline.

\subsection{PURPOSE}

This functions and requirements (F\&R) documentation has been developed to obtain concurrence from the U. S. Department of Energy, Richland Operations Office (RL) of its technical baseline. This F\&R has been generated to meet the requirements of:

1. HNF-3552, "Spent Nuclear Fuel Project Execution Plan" (PEP) (FDH 1998b), Section 7.0, Engineering/Design, and

2. WHC-SD-SNF-SEMP-001, SEMP Section 3.1, Integrated SNF Project Engineering Process, and Section 3.6.2, Functions and Requirements Documentation (WHC 1996a). 
This F\&R document details the Transition Project operating objectives, top-level functions, and requirements. This information is the basis for further development of the Transition Project technical baseline. Transition Project technical information, processes, and products are to be developed from and traceable to the information contained in this $\mathrm{F} \& \mathrm{R}$. 


\subsection{OVERVIEW}

This section provides the Transition Project mission and its work scope.

\subsection{MISSION STATEMENT}

The Transition Project mission is develop the strategy, process, and acquire facilities, systems, and equipment so that operations can transition the $100 \mathrm{~K}$ Area Facilities to Environmental Restoration (ER). The Transition Project mission is derived from SNF Project treatment, storage, and disposal (TSD) function TSD.2.1.4.2.1, Transition $100 \mathrm{~K}$ Area Facilities, as depicted in Figure 3-1, Transition Project Function Hierarchy. The Transition Project function decomposition and hierarchy identification will follow the Hanford Site identification system, using the TSD prefix.

\subsection{SCOPE}

The scope of the Transition Project is derived from the SNF Project Mission contained in the MYWP. For the existing 100 Area K Basin Facilities, the Transition Project will acquire the systems, facilities, equipment, and complete facility modifications necessary to support transition to ER. The Transition Project acquisition occurs under the SNF Project function titled Manage Transition Activities, TSD.2.1.4.2.1.1, so that operations can perform functions tsd.2.1.4.2.1.2, Transition K Basin Facilities, and tsd.2.1.4.2.1.3, Transition Other $100 \mathrm{~K}$ Area Facilities.

\subsection{TECHNICAL BASELINE DEVELOPMENT}

Site Systems Engineering allocated top-level functions and requirements to the major facilities that will be employed to achieve the Hanford Site mission objectives. Site Systems Engineering, in conjunction with SNF Project Systems Engineering, allocated top-level functions and requirements to the major facilities that will be employed to achieve the SNF Project mission objectives. These major facilities and associated functions and requirements provide the basis for further SNF Project functions and requirements analysis. This $F \& R$ document contains the first Transition Project functional analysis of the top-level SNF Project mission analysis results, as documented in the MYWP. This function analysis is the defined function set that accomplishes the parent function, Transition $100 \mathrm{~K}$ Area Facilities. The functions and requirements analysis results will be used for further project development and design implementation activities. 


\subsubsection{TRANSITION PROJECT TECHNICAL BASELINE DEVELOPMENT}

The initial functions and requirements analysis has been conducted to provide a hierarchy of functions and requirements that support the development of a traceable and defensible top-down system configuration. This configuration, or architecture, has been used to develop the work breakdown structure, providing integration with the cost and schedule baselines. The end goal is to generate appropriate performance specifications that contain the requirements for Transition Project activities.

The Transition of the $100 \mathrm{~K}$ Area facilities was added to the SNF Project at the direction of RL (BCR, SNF-1998-015 1998). This work-scope description has not been previously fully developed and integrated. A subsequent Baseline Change Request (BCR, PK11999-002 1999) resulted in modifying the SNF Project Work Breakdown Structure (WBS). Debris/Sludge activities within the SNF Project, which did not support fuel movement, were integrated into the Transition Project scope of work. This included Sludge Removal, Sludge Handling, and Debris Removal. Previously, Sludge Removal and Debris Removal were developed from SNF Project functions Design/Modify/Construct Systems for Fuel Removal, Operate SNF Removal Systems, Design/Modify/Construct Sludge Removal System, and Operate \& Maintain Sludge Removal System. Those activities, which do not support SNF Removal, will now be developed from the Transition $100 \mathrm{~K}$ Area Facilities function during the Post-Operations phase. The Transition Project technical baseline will be developed in accordance with the requirements of the SNF Project SEMP (WHC 1996a), as tailored to meet their needs. SEMP Section 3.3, Technical Baseline, describes the baseline development process.

\subsubsection{TECHNICAL BASELINE PRODUCTS}

Since Sludge Removal and Debris Removal Project activities were in process at the time of the Transition $100 \mathrm{~K}$ Area Facilities addition to the SNF Project, blending of existing and new technical documentation needs to take place. A document analysis was performed to determine what technical documentation exists, what document changes need to occur, and what documentation needs to be developed. A document tree, Figure 2-1, graphically displays the Transition Project technical baseline documents. An analysis of existing and future technical baseline documents follows.

\subsubsection{DEBRIS REMOVAL}

1. WHC-SD-SNF-FRD-009, "Functions \& Requirements for Debris Removal Subproject", Revision 0 (Yanochko 1997) - This document identified the functions, requirements, architecture, interfaces, decisions, and alternatives applicable to the Debris Removal System. This was the top-level technical baseline document covering all cooling-pool Debris Removal activities. 
Document Analysis - This document needs to be updated to delete those debris activities not related to SNF removal from the basins. Those debris functions and requirements related to transition will be incorporated into the Transition Project F\&R document and/or the Transition Project database. This document will not be part of the Transition Project technical baseline. This document will remain in the technical baseline supporting SNF removal from the Basins.

2. WHC-SD-SNF-FRD-018, "Functions and Requirements for Debris Removal from 105-KE Basin South Loadout Pit", Revision 0 (Crystal 1995) - This document provides the functions and requirements associated with cleanout of the $105 \mathrm{KE}$ Basin South Loadout Pit in support of fuel retrieval.

Document Analysis - This is a sub-tier document to WHC-SD-SNF-FRD-009. This document will not be part of the Transition Project technical baseline. This document will remain in the technical baseline supporting SNF removal from the Basins.

3. HNF-SD-SNF-FRD-021 "Functions and Requirements for the Dummy Elevator Pit Debris Removal Project at the 105 KE Basin", Revision 1 (Huisingh 1997). The Dummy Elevator Pit debris Removal System moves sludge from the Dummy Elevator Pit to the Weasel Pit, removes and disposes of debris in the Dummy Elevator Pit, debris at the entry to the Weasel Pit, debris presently located in the $105 \mathrm{KE}$ Fuel Storage Basin, fuel storage hangers, and sufficient amounts of other debris to allow the removal of sludge and fuel from the Basins. This document provides functions and requirements, and operating criteria.

Document Analysis - This is a sub-tier document to WHC-SD-SNF-FRD-009. This document will not be part of the Transition Project technical baseline. This document will remain in the technical baseline supporting SNF removal from the Basins.

4. Debris Related Transition Project Documentation - Any new debris removal documentation associated with Transition Project activities will be developed from the Transition Project functions and requirements database. New debris-related Transition Project documentation would be provided in a specification format.

Document Analysis - New technical documentation will, as a minimum, be specifications, such as for Fuel Rack Removal. New specification(s) may be identified as the technical baseline develops.

\subsubsection{SLUDGE REMOVAL}

1. HNF-SD-SNF-FDC-004, "Functional Design Criteria for the K Basins Sludge Removal System", Revision 1 (Precechtel 1998) - This was the top-level technical baseline document covering all Sludge Removal activities. Lower level Sludge Removal Project documentation is derived from this top-level F\&R. This document established the functional design requirements for the Sludge Removal System, Project A.13, the disposition of $\mathrm{K}$ Basins sludge. This document contains project 
criteria, requirements, facility requirements, process criteria, facility criteria, and general criteria, such as safety, criticality, As Low As Reasonable Achievable (ALARA), environmental protection, Quality Assurance, and applicable requirement sources.

Document Analysis - It is intended to supersede this document and appropriate information gets integrated with the Transition Project F\&R. Requirements would be captured in the Transition Project requirement database. It is intended that lowerlevel technical documentation be traceable to the Transition Project F\&R document via the requirement database. In addition, lower-level baseline documents will be updated to reflect applicable requirements contained in this functional design criteria (FDC). This document will be superseded.

2. HNF-SD-SNF-FDC-005, "Functional Design Criteria for the K Basins Sludge Retrieval System", Revision 1 (Precechtel 1998) - This document provided the functions and design requirements for the Floor Sludge Retrieval sub-project in 105 $\mathrm{KE}$ and $105 \mathrm{KW}$ Basins. This is a sub-tier document to HNF-SD-SNF-FDC-004. The KE and KW Basin Sludge Retrieval Systems (RS) shall comply with all applicable requirements in HNF-SD-SNF-FDC-004. This document establishes the functions and design requirements for the Floor Sludge Retrieval sub-project in the $105 \mathrm{KE}$ and $105 \mathrm{KW}$ Basins.

Document Analysis - This document is to be retained. The sludge RS is currently being designed to requirements contained in this document. Sludge retrieval construction drawings and specifications are currently under development. This document will become part of the Transition Project technical baseline. This document will need revision to reflect the top-level Transition Project F\&R and superseding of HNF-SD-SNF-FDC-004.

3. WHC-SD-SNF-FDC-006, "Functional Design Criteria for the K Basins Sludge Process and Loadout System", Revision 1 (Precechtel 1996) - This FDC applies only to the K Basins Sludge Process and Loadout System and is a sub-tier document to HNF-SD-SNF-FDC-004. The K Basins Sludge Process and Loadout System is to comply with all applicable requirements in the aforementioned document. This document identifies and/or provides design interface requirements for the loadout process. The document scope is to provide design requirements for a system for transferring sludge from an in-basin location to a container for shipment to the Tank Waste Remediation System (TWRS). TWRS is now known as the River Protection Project (RPP). This document is the technical basis for completing the preliminary design phase of sludge loadout.

Document Analysis - This document is to be retained. It will need to be revised to reflect requirements for sludge load-out at $\mathrm{K}$ Basins. This document will become part of the Transition Project technical baseline. This document will need revision to reflect the top-level Transition Project F\&R and superseding of HNF-SD-SNF-FDC-004. 
4. WHC-SD-TP-PDC-035, "Packaging Design Criteria for the K East Basin Sludge Transportation System", Revision 0 (Tomazewski 1996) - This document provides the onsite transportation safety criteria for a reusable packaging and transport system to transport KE Basin sludge and water. The packaging design criteria (PDC) provides the basis for the development of a Safety Analysis Report for Packaging (SARP), establishes the packaging contents and safety class of the package, and provides design criteria for the package, packaging, and transport system. This document is the technical basis for completing the preliminary design phase of the sludge onsite transportation system.

Document Analysis - The current disposition path for sludge is to T Plant. This document needs to be updated with one providing the specification for packaging and transportation to interim storage at T-Plant. This document will become part of the Transition Project technical baseline.

5. WHC-SD-WM-FDC-052."Functional Design Criteria for Sludge Receiving Station," Revision 0 (Brisbin 1996) - This document applicable to the Sludge Receiving Station, is a sub-tier to WHC-SD-SNF-FDC-004. The Sludge Receiving Station is to comply with all applicable requirements of the aforementioned document. The document purpose is to provide the detailed functions and design requirements for the Sludge Receiving Station. The scope of this activity is to provide a system allowing for direct offloading of sludge from the Sludge Transportation System into a doubleshell tank (DST). This document is the technical basis for completing the preliminary design phase of the Sludge Receiving Station.

Document Analysis - The current disposition path for sludge is to T Plant. This document needs to be updated with one providing the specification for receiving sludge for interim storage at T Plant. The revised document will become part of the Transition Project technical baseline.

\subsubsection{Water Removal System}

The technical baseline for removing water from the $\mathrm{K}$ Basin cooling pools has not been developed. Specifications will be provided, which document the functions and requirements for the water removal system.

\subsubsection{Systems and Equipment Stabilization System}

The technical baseline for systems and equipment stabilization has not been developed. Any new documents will be developed from the Transition Project functions and requirements and provided in a specification format. Specifications may be provided, which document the functions and requirements for deactivating systems and equipment. 


\subsubsection{Facility Stabilization System}

The technical baseline for facility stabilization has not been developed. Any new documents will be developed from the Transition Project functions and requirements and provided in a specification format. Specifications may be provided, which document the functions and requirements for facility upgrades, decontamination or fixation/stabilization of walls and floors, etc.

\subsubsection{Waste Management System}

The technical baseline for facility stabilization has not been developed. Any new documents will be developed from the Transition Project functions and requirements and provided in a specification format. Specifications may be provided, which document the functions and requirements for waste preparation and disposal.

\subsubsection{DOCUMENT HIERARCHY}

Transition Project products and documentation are depicted in Figure 2-1. This tree displays the results of the document analysis and identifies other Transition Project products and associated documents. The product tree displays the deliverable systems and documents that are required to meet Transition Project objectives. This product tree is a further expansion of the SNF Project Product Tree, Figure 8-2, contained in WHC-SD-SNF-SD-005, "Spent Nuclear Fuel Project Technical Baseline Description Fiscal Year 1996" (WHC 1996b). This product tree will be updated as the Transition Project technical baseline develops. 
Figure 2-1 TRansition Project Document Tree

(SHEET 1 OF 3)




SNF-4961, Rev. 0

\section{Figure 2-1 Transition Project Document Tree \\ (SHeET 2 OF 3)}

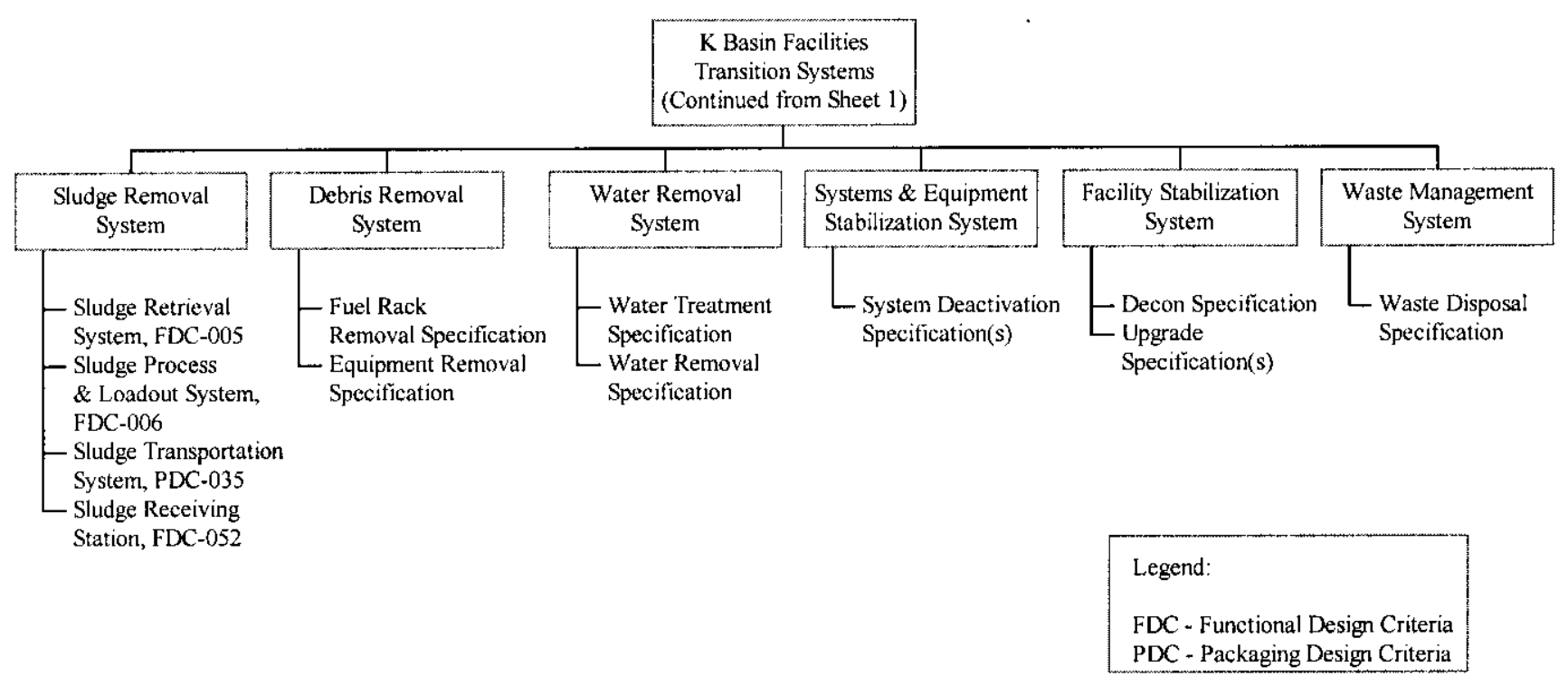


SNF-4961, Rev. 0

Figure 2-1 Transition Project Document Tree

(SHEET 3 OF 3)






\subsection{FUNCTIONS}

This section provides the Transition Project functional analysis results. The functional analysis was performed meeting the intent of SEP-3.0, "System Function Definition" (WHC 1995b).

\subsection{FUNCTION HIERARCHY}

The SNF Project functional analysis results show the functional decomposition of the fifth-level SNF Project Function tsd.2.1.4.2.1, Transition $100 \mathrm{~K}$ Area Facilities. This function needed further definition (expansion/focus) to define the Transition Project specific activities. When met, the functions identified accomplish the Transition Project mission. This function decomposition (hierarchy) is depicted in Figure 3-1.

\subsection{FUNCTION DEFINITIONS}

The system function definitions are provided in Table 3-1. This table is the dictionary for subproject system functions, presenting the number, title, and definition.

\section{Table 3-1. Transition Function Definitions}

\begin{tabular}{|l|l|}
\hline $\begin{array}{l}\text { tsd.2.1.4.2.1, } \\
\text { Transition 100 K } \\
\text { Area Facilities }\end{array}$ & $\begin{array}{l}\text { Perform the facility transition phase and initiate decontamination and } \\
\text { deactivation for K Basins, including debris removal, basin water removal, } \\
\text { and tritium reduction process. Also included are the remaining systems } \\
\text { upon removal of sludge and SNF. Transfers the deactivated K Basins to } \\
\text { decommissioning and decontamination (D\&D). }\end{array}$ \\
\hline $\begin{array}{l}\text { Msd.2.1.4.2.1.1, } \\
\text { Activities }\end{array}$ & $\begin{array}{l}\text { Provide all planning, management direction, evaluation, and the } \\
\text { management system for transitioning 100 K Area Facilities. Provide the } \\
\text { management needed to conduct the mission. Specify management } \\
\text { procedures, provide configuration management, perform scheduling, } \\
\text { allocate all resources, define performance criteria, and resolve regulatory } \\
\text { problems. Includes integrating activities, defining technical baseline } \\
\text { development, providing support services, and managing regulatory } \\
\text { compliance. }\end{array}$ \\
\hline tsd.2.1.4.2.1.1.1, & $\begin{array}{l}\text { Assess the current state of all K Basins facilities. Identify and/or } \\
\text { negotiate material and equipment disposition requirements. Develop } \\
\text { plans to turnover to Environmental Restoration Projects. Negotiate and } \\
\text { administratively maintain the desired K Basins turnover endpoint } \\
\text { specifications. Plan operations to support debris, sludge, and water } \\
\text { removal plans, operations for debris and sludge retrieval/removal and } \\
\text { basin water treatment system. Establish and maintain an archive of K } \\
\text { Basins information. }\end{array}$ \\
\hline
\end{tabular}




\section{SNF-4961, Rev. 0}

Figure 3-1. Transition Project Function Hierarchy

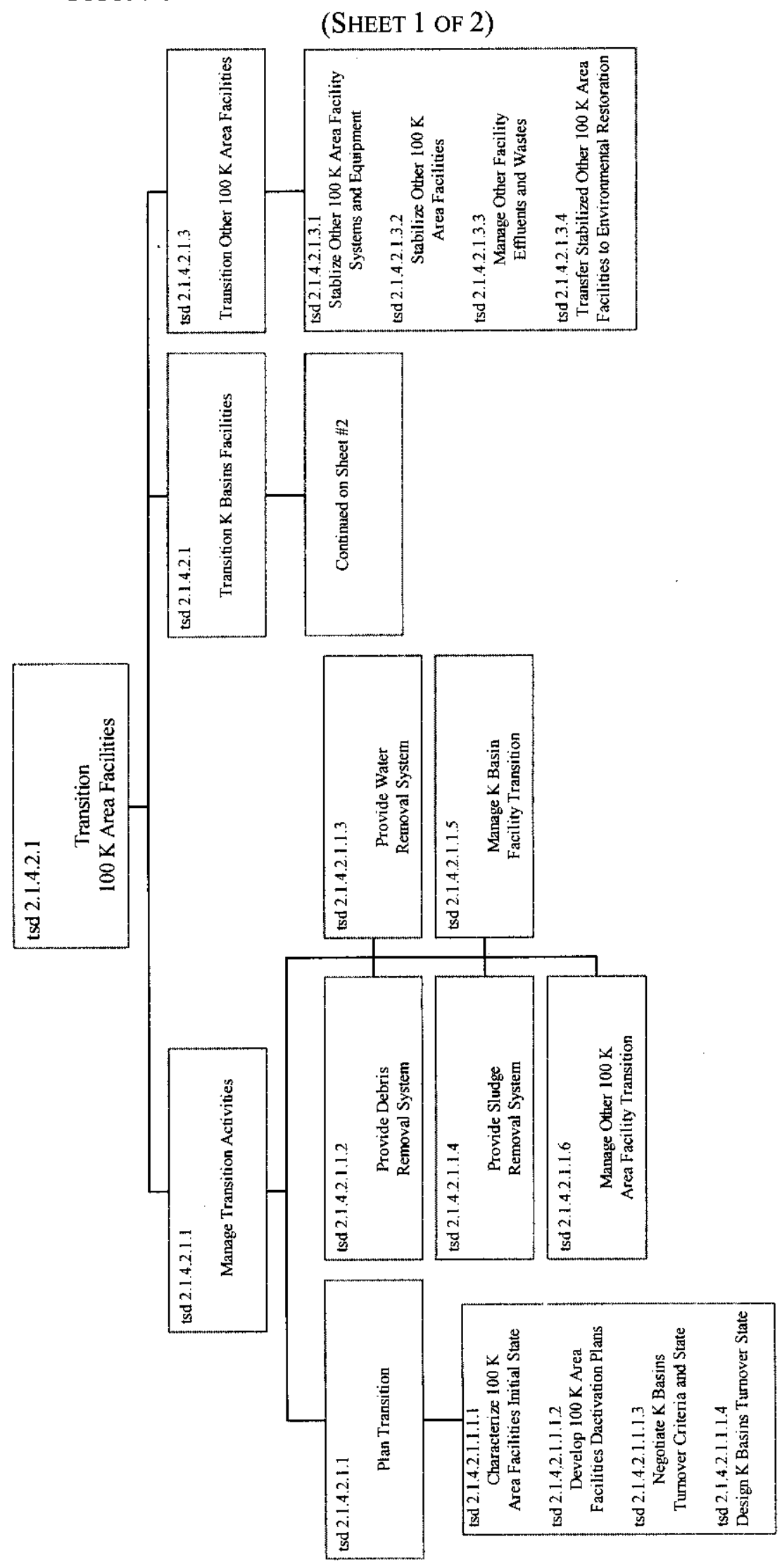


SNF-4961, Rev. 0

Figure 3-1. Transition Project Function Hierarchy

(SHEET 2 OF 2)

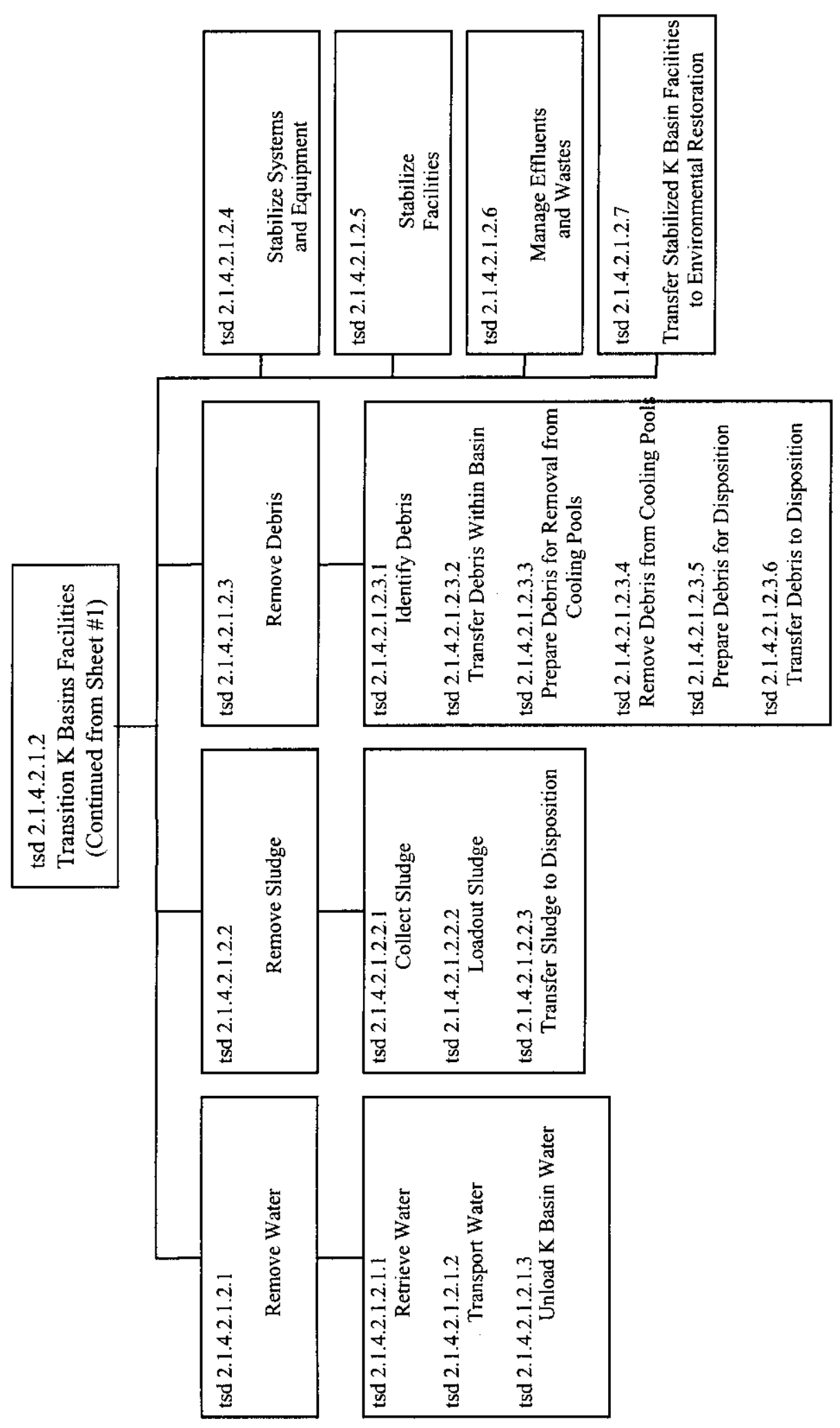




\begin{tabular}{|c|c|}
\hline $\begin{array}{l}\text { tsd.2.1.4.2.1.1.1.1, } \\
\text { Characterize } 100 \mathrm{~K} \\
\text { Area Facilities } \\
\text { Initial State }\end{array}$ & $\begin{array}{l}\text { Define the current state of K Basins infrastructure, process systems, } \\
\text { support systems, inventory, equipment, instrumentation and utility } \\
\text { systems. }\end{array}$ \\
\hline $\begin{array}{l}\text { tsd.2.1.4.2.1.1.1.2, } \\
\text { Develop 100 K Area } \\
\text { Facilities } \\
\text { Deactivation Plans }\end{array}$ & $\begin{array}{l}\text { Develop strategies and plans for turnover to ER. Identify requirements } \\
\text { for disposition of facilities, systems, and equipment, including } \\
\text { infrastructure supporting debris removal, sludge retrieval/removal, and } \\
\text { water treatment. Negotiate disposition requirements with authorities and } \\
\text { stakeholders, as appropriate. Plan addresses documentation } \\
\text { requirements, checklists, accountability, occurrence reports, } \\
\text { administrative records, Certified Vendor Information (CVI), etc. }\end{array}$ \\
\hline $\begin{array}{l}\text { tsd.2.1.4.2.1.1.1.3, } \\
\text { Negotiate K Basins } \\
\text { Turnover Criteria } \\
\text { and State }\end{array}$ & $\begin{array}{l}\text { Negotiate conditions and criteria for turnover of resources to Transition } \\
\text { Projects. }\end{array}$ \\
\hline $\begin{array}{l}\text { tsd.2.1.4.2.1.1.1.4, } \\
\text { Design K Basins } \\
\text { Turnover State }\end{array}$ & $\begin{array}{l}\text { Develop turnover specification and supporting documentation. Identify } \\
\text { equipment and material status and provide supporting analyses and test } \\
\text { data. }\end{array}$ \\
\hline $\begin{array}{l}\text { tsd.2.1.4.2.1.1.2, } \\
\text { Provide Debris } \\
\text { Removal System }\end{array}$ & $\begin{array}{l}\text { Manage, define, design, fabricate, and modify existing facilities and } \\
\text { systems; procure, test, deliver, obtain approvals and permits, and accept } \\
\text { the debris removal system and equipment to support the transfer of debris } \\
\text { to solid waste for interim storage. Provide all new intellectual and } \\
\text { physical resources, including personnel, consultants, services, supplies, } \\
\text { equipment, operational documentation, construction, and subcontracts of } \\
\text { all kinds. }\end{array}$ \\
\hline $\begin{array}{l}\text { tsd.2.1.4.2.1.1.3, } \\
\text { Provide Water } \\
\text { Removal System }\end{array}$ & $\begin{array}{l}\text { Manage, define, design, fabricate, and modify existing facilities and } \\
\text { systems; procure, test, deliver, obtain approvals and permits, and accept } \\
\text { the water treatment system and equipment to clean process water at } \\
\text { K Basins. Provide all new intellectual and physical resources, including } \\
\text { personnel, consultants, services, supplies, equipment, operational } \\
\text { documentation, construction, and subcontracts of all kinds. }\end{array}$ \\
\hline $\begin{array}{l}\text { tsd.2.1.4.2.1.1.4, } \\
\text { Provide Sludge } \\
\text { Removal System }\end{array}$ & $\begin{array}{l}\text { Manage, define, design, fabricate, and modifies existing K Basin and } \\
\text { T Plant facilities and systems; procure, test, deliver, obtain approvals and } \\
\text { permits, and accept the sludge removal system and equipment to support } \\
\text { transfer of sludge from the K Basins to interim storage. Provide all new } \\
\text { intellectual and physical resources, including personnel, consultants, } \\
\text { services, supplies, equipment, operational documentation, construction, } \\
\text { and subcontracts of all kinds. }\end{array}$ \\
\hline
\end{tabular}




\begin{tabular}{|c|c|}
\hline $\begin{array}{l}\text { tsd.2.1.4.2.1.1.5, } \\
\text { Manage K Basin } \\
\text { Facility Transition }\end{array}$ & $\begin{array}{l}\text { Provide all planning, management direction, evaluation, and the } \\
\text { management system for K Basin Facility Transition. Provide the } \\
\text { management needed to conduct the mission. Specify management } \\
\text { procedures, provide configuration management, perform scheduling, } \\
\text { allocate all resources, define performance criteria, and resolve regulatory } \\
\text { problems. Includes integrating activities, defining technical baseline } \\
\text { development, providing support services, and managing regulatory } \\
\text { compliance. }\end{array}$ \\
\hline $\begin{array}{l}\text { tsd.2.1.4.2.1.1.6, } \\
\text { Manage Other 100K } \\
\text { Area Facility } \\
\text { Transition }\end{array}$ & $\begin{array}{l}\text { Provide all planning, management direction, evaluation, and the } \\
\text { management system for Other } 100 \mathrm{~K} \text { Area Facilities. Provide the } \\
\text { management needed to conduct the mission. Specify management } \\
\text { procedures, provide configuration management, perform scheduling, } \\
\text { allocate all resources, define performance criteria, and resolve regulatory } \\
\text { problems. Includes integrating activities, defining technical baseline } \\
\text { development, providing support services, and managing regulatory } \\
\text { compliance. }\end{array}$ \\
\hline $\begin{array}{l}\text { tsd.2.1.4.2.1.2, } \\
\text { Transition K Basin } \\
\text { Facilities }\end{array}$ & $\begin{array}{l}\text { Prepare the K Basin facilities to meet end-point criteria for transitioning } \\
\text { to ER. Stabilizes facilities, equipment \& systems, manages effluents \& } \\
\text { wastes, removes water, sludge, debris, and transfers stabilized facilities to } \\
\text { ER. Transport water, sludge, and debris to disposition. }\end{array}$ \\
\hline $\begin{array}{l}\text { tsd.2.1.4.2.1.2.1, } \\
\text { Remove Water }\end{array}$ & $\begin{array}{l}\text { Remove, condition, and transfer contaminated water from the K Basins to } \\
\text { disposition Effluent Treatment Facility (ETF) or Liquid Effluent } \\
\text { Retention Facility (LERF), as directed by Waste Programs Division } \\
\text { (WPD). Includes pre-treating, sampling and analyzing, acquisition, } \\
\text { installation, and startup of facilities, systems, and/or equipment to } \\
\text { support removal from the K Basins to meet disposition criteria. }\end{array}$ \\
\hline $\begin{array}{l}\text { tsd.2.1.4.2.1.2.1.1, } \\
\text { Retrieve Water }\end{array}$ & $\begin{array}{l}\text { Remove water from the K Basin cooling pools. Includes loading } \\
\text { transporter, pre-treating, sampling and analyzing, to meet waste } \\
\text { acceptance criteria of ETF. }\end{array}$ \\
\hline $\begin{array}{l}\text { tsd.2.1.4.2.1.2.1.2, } \\
\text { Transport Water }\end{array}$ & $\begin{array}{l}\text { Transfer contaminated water, which meets acceptance criteria, to } \\
\text { disposition, ETF or LERF. }\end{array}$ \\
\hline $\begin{array}{l}\text { tsd.2.1.4.2.1.2.1.3, } \\
\text { Unload K Basin } \\
\text { Water }\end{array}$ & $\begin{array}{l}\text { Unload K Basin water at disposition facilities. Transfers responsibility of } \\
\text { contaminated water to ETF or LERF. Return empty transporter to } \mathrm{K} \\
\text { Basins. Positions transporter at K Basin facilities. Rinse and flush } \\
\text { transporter for the removal of loose contamination to a condition suitable } \\
\text { for further use of transporting contaminated liquids. }\end{array}$ \\
\hline $\begin{array}{l}\text { tsd.2.1.4.2.1.2.2, } \\
\text { Remove Sludge }\end{array}$ & $\begin{array}{l}\text { Receive, retrieve, stage, and processes sludge. Prepares sludge for } \\
\text { off-loading to T Plant. Operate and maintain the K Basins sludge } \\
\text { removal systems and equipment. Includes acquisition, installation, and } \\
\text { startup of facilities, systems, and/or equipment to support removal from } \\
\text { the K Basins. }\end{array}$ \\
\hline $\begin{array}{l}\text { tsd.2.1.4.2.1.2.2.1, } \\
\text { Collect Sludge }\end{array}$ & $\begin{array}{l}\text { Retrieve sludge from floor and pit areas (weasel pit and tech view pit) of } \\
\mathrm{K} \text { Basins to interim staging area. Maintain safe and compliant conditions } \\
\text { within staging area. }\end{array}$ \\
\hline
\end{tabular}




\begin{tabular}{|c|c|}
\hline $\begin{array}{l}\text { tsd.2.1.4.2.1.2.2.2, } \\
\text { Loadout Sludge }\end{array}$ & $\begin{array}{l}\text { Transfer collected sludge to transporter. Sludge that has been collected } \\
\text { from the Basin floors, pit areas, interim staging areas, and Integrated } \\
\text { Water Treatment System (IWTS). Load transportation container. } \\
\text { Maintain safe and compliant conditions. Includes material sampling and } \\
\text { analysis. }\end{array}$ \\
\hline $\begin{array}{l}\text { tsd.2.1.4.2.1.2.2.3, } \\
\text { Transfer Sludge to } \\
\text { Disposition }\end{array}$ & $\begin{array}{l}\text { Move sludge transporter, containing sludge, to interim storage. Returns } \\
\text { empty transporter to K Basins. Position empty transporter at K Basin } \\
\text { facilities. }\end{array}$ \\
\hline $\begin{array}{l}\text { tsd.2.1.4.2.1.2.3 } \\
\text { Remove Debris }\end{array}$ & $\begin{array}{l}\text { Perform all in-pool debris related activities required to meet end point } \\
\text { criteria subsequent to SNF removal. Includes acquisition, installation, } \\
\text { and startup of facilities, systems, and/or equipment to support removal } \\
\text { from the K Basins. }\end{array}$ \\
\hline $\begin{array}{l}\text { tsd.2.1.4.2.1.2.3.1, } \\
\text { Identify Debris }\end{array}$ & $\begin{array}{l}\text { Perform activities to determine the waste classification of debris to } \\
\text { ensure debris is disposed of in the proper manner. }\end{array}$ \\
\hline $\begin{array}{l}\text { tsd.2.1.4.2.1.2.3.2, } \\
\text { Transfer Debris } \\
\text { Within Basin }\end{array}$ & Transfer debris to process stations within cooling pools as required. \\
\hline $\begin{array}{l}\text { tsd.2.1.4.2.1.2.3.3, } \\
\text { Prepare Debris for } \\
\text { Removal from } \\
\text { Cooling Pools }\end{array}$ & $\begin{array}{l}\text { Prepare debris to meet (ALARA) goals, waste packaging criteria. } \\
\text { Includes volume reduction, as required. }\end{array}$ \\
\hline $\begin{array}{l}\text { tsd.2.1.4.2.1.2.3.4, } \\
\text { Remove Debris } \\
\text { from Cooling Pools }\end{array}$ & Remove debris out of the $\mathrm{K}$ Basin cooling pools for packaging. \\
\hline $\begin{array}{l}\text { tsd.2.1.4.2.1.2.3.5, } \\
\text { Prepare Debris for } \\
\text { Disposition }\end{array}$ & $\begin{array}{l}\text { Package retrieved debris to enable handling and transportation to final } \\
\text { disposal. Obtain the necessary packaging materials, waste containers, } \\
\text { reusable debris containers, debris preparation, and container loading. } \\
\text { Identify packaging material needs, acquire packaging materials, verify } \\
\text { packaging material inventory, deliver packaging, and stage packaging } \\
\text { materials. }\end{array}$ \\
\hline $\begin{array}{l}\text { tsd.2.1.4.2.1.2.3.6, } \\
\text { Transfer Debris to } \\
\text { Disposition }\end{array}$ & $\begin{array}{l}\text { Provide for all activities to enable final disposition of retrieved debris. } \\
\text { Includes the arrangements for and obtaining the necessary transporters, } \\
\text { loading of filled waste containers onto transporters, and shipping filled } \\
\text { waste containers to the disposal and/or storage site. }\end{array}$ \\
\hline $\begin{array}{l}\text { tsd.2.1.4.2.1.2.4, } \\
\text { Stabilize Systems } \\
\text { and Equipment }\end{array}$ & $\begin{array}{l}\text { Perform the transition of systems, and equipment to meet end point } \\
\text { criteria. Includes remaining systems upon removal of SNF. Deactivate } \\
\text { nonessential systems, system components, and physical structures. Take } \\
\text { other actions, as required to minimize environmental, public and } \\
\text { personnel hazards; ensure actions taken are consistent with minimizing } \\
\text { continuing K Basins costs. Transfer deactivated K Basin Facility systems } \\
\text { and equipment to ER. Includes draining, de-energizing, material } \\
\text { removal, (hazardous, asbestos, etc.), characterization, radiological source } \\
\text { reduction, downgrading, etc. Systems and equipment include tanks, } \\
\text { vessels, drums, elevators, cranes, water system(s), electrical systems(s), } \\
\text { fire protection system(s). }\end{array}$ \\
\hline
\end{tabular}




\begin{tabular}{|c|c|}
\hline $\begin{array}{l}\text { tsd.2.1.4.2.1.2.5, } \\
\text { Stabilize Facilities }\end{array}$ & $\begin{array}{l}\text { Deactivate structural components and physical structures. Take other } \\
\text { actions, as required to minimize environmental, public and personnel } \\
\text { hazards; ensure actions taken are consistent with minimizing continuing } \\
\text { K Basins costs. Includes physical structure and auxiliary structures, and } \\
\text { tanks. Activities include characterization, radiological source reduction } \\
\text { of walls and floors, access regulation, effluent isolation, rodent control, } \\
\text { final surveys, repairs, etc. }\end{array}$ \\
\hline $\begin{array}{l}\text { tsd.2.1.4.2.1.2.6, } \\
\text { Manage Effluents } \\
\text { and Wastes }\end{array}$ & $\begin{array}{l}\text { Accumulate, package, and disposition resources and waste at K Basins. } \\
\text { Includes characterization and classification of waste materials, treating } \\
\text { and packaging waste according to classification and waste type (solid, } \\
\text { liquid, gaseous). Store treated waste(s) in accordance with environmental } \\
\text { regulations and requirements. Transfer waste(s) generated during } \\
\text { transition activities. Includes hazardous materials, radioactive waste, } \\
\text { preparation, removal, and transfer. }\end{array}$ \\
\hline $\begin{array}{l}\text { tsd.2.1.4.2.1.2.7, } \\
\text { Transfer Stabilized } \\
\text { K Basin Facilities to } \\
\text { Environmental } \\
\text { Restoration }\end{array}$ & $\begin{array}{l}\text { Transfer responsibility for } \mathrm{K} \text { Basin facilities to } \mathrm{D} \& \mathrm{D} \text { organization for } \\
\text { remediation. Includes downgrading authorization basis, accountability, } \\
\text { etc. }\end{array}$ \\
\hline $\begin{array}{l}\text { tsd.2.1.4.2.1.3, } \\
\text { Transition Other } \\
\text { 100 K Area } \\
\text { Facilities }\end{array}$ & $\begin{array}{l}\text { Prepare the } 100 \mathrm{~K} \text { Area facilities to meet end-point criteria for } \\
\text { transitioning to ER. Stabilize facilities, equipment \& systems, manage } \\
\text { effluents \& wastes, and transfers stabilized facilities to ER. }\end{array}$ \\
\hline $\begin{array}{l}\text { tsd.2.1.4.2.1.3.1, } \\
\text { Stabilize Other } 100 \\
\text { K Area Facilities } \\
\text { Systems and } \\
\text { Equipment }\end{array}$ & $\begin{array}{l}\text { Perform the transition of systems, and equipment to meet end point } \\
\text { criteria. Includes remaining systems upon removal of SNF. Deactivate } \\
\text { nonessential systems, system components, and physical structures. Take } \\
\text { other actions, as required to minimize environmental, public and } \\
\text { personnel hazards; ensure actions taken are consistent with minimizing } \\
\text { continuing } 100 \mathrm{~K} \text { Area facility costs. Transfer deactivated facility } \\
\text { systems and equipment to ER. Includes draining, de-energizing, material } \\
\text { removal, (hazardous, asbestos, etc.), characterization, radiological source } \\
\text { reduction, downgrading, etc. Systems and equipment include tanks, } \\
\text { vessels, drums, elevators, cranes, water system(s), electrical systems(s), } \\
\text { fire protection system(s). }\end{array}$ \\
\hline $\begin{array}{l}\text { tsd.2.1.4.2.1.3.2, } \\
\text { Stabilize Other } 100 \\
\text { K Area Facilities }\end{array}$ & $\begin{array}{l}\text { Deactivate structural components and physical structures. Take other } \\
\text { actions, as required to minimize environmental, public, and personnel } \\
\text { hazards; ensure actions taken are consistent with minimizing continuing } \\
100 \mathrm{~K} \text { Area costs. Includes physical structure and auxiliary structures, } \\
\text { and tanks. Activities include characterization, radiological source } \\
\text { reduction, access regulation, effluent isolation, rodent control, final } \\
\text { surveys, repairs, etc. }\end{array}$ \\
\hline
\end{tabular}




\begin{tabular}{|c|c|}
\hline $\begin{array}{l}\text { tsd.2.1.4.2.1.3.3, } \\
\text { Manage Other } \\
\text { Facility Effluents } \\
\text { and Wastes }\end{array}$ & $\begin{array}{l}\text { Accumulate, package, and disposition resources and waste at } 100 \mathrm{~K} \text { Area } \\
\text { Facilities. Includes characterization and classification of waste materials, } \\
\text { treating and packaging waste according to classification and waste type } \\
\text { (solid, liquid, gaseous). Store treated waste(s) in accordance with } \\
\text { environmental regulations and requirements. Transfers waste(s) } \\
\text { generated during transition activities. Includes hazardous materials, } \\
\text { radioactive waste, preparation, removal, and transfer. }\end{array}$ \\
\hline $\begin{array}{l}\text { tsd.2.1.4.2.1.3.4, } \\
\text { Transfer Stabilized } \\
\text { Other } 100 \mathrm{~K} \text { Area } \\
\text { Facilities to } \\
\text { Environmental } \\
\text { Restoration }\end{array}$ & $\begin{array}{l}\text { Transfer responsibility for Other } 100 \mathrm{~K} \text { Area Facilities to } \mathrm{D} \& \mathrm{D} \\
\text { organization for remediation. Includes downgrading authorization basis, } \\
\text { accountability, etc. }\end{array}$ \\
\hline
\end{tabular}




\subsection{REQUIREMENTS}

This section identifies the Transition Project requirement baseline. It consists of requirement source documents and mission requirements. The requirements are derived from HNF-SP-1104, "Spent Fuels Multi-Year Work Plan", (FDH 1998a), Hanford Site Environmental Management Specification, DOE/RL-97-55 (DOE/RL), Contract No. DE-AC06-96RL13200, Modification M071, Hanford Federal Facility Agreement and Consent Order (Tri-Party Agreement), Revision 5, DOE/RL-89-10, and the Spent Nuclear Fuel Project Technical Baseline Description Fiscal Year 1996, WHC-SD-SNF-SD-005 (WHC 1996b). The requirements include Federal and State Regulations and Standards, the U.S. Department of Energy (DOE) Orders, directives and implementing procedures, formal agreements, contracts, and external project agreements.

The Transition Project requirement definition activity was performed meeting the intent of SEP-4.0, "Requirements Identification \& Allocation", (WHC 1995c). As the Transition Project element design, procurement, construction, and testing activities evolve, the requirement documents identified in this section are evaluated and compiled into specifications, as applicable. Many requirements will also be derived from studies and analyses that will be performed as part of the project design and development effort. These requirements are not part of the top-level mission requirements.

Table 4-1 lists top-level mission requirements and requirement source documents, which are uniquely applicable to Transition Project functions. The Transition Project requirement database contains the complete requirement definition details, including:

1. Justifications and rationale,

2. Requirement definition from applicable source documents, and

3. Function allocation.

The requirement definition, analysis, and allocation details are to be developed separately.

\subsection{MISSION REQUIREMENTS}

Top-level mission requirements are used as the primary or "driver" requirements for Transition Project requirement analyses. This section lists top-level mission requirements and sources for the Transition Project. Mission requirements include requirements derived from the Hanford Strategic Plan (HSP) interim and final end points as well as:

1. "Hanford Remedial Action Environmental Impact Statement and Comprehensive Land Use Plan", DOE/EIS-0222D,

2. "Hanford Site Environmental Management Specification", DOE/RL-97-55,

3. "Contract No. DE-AC06-96RL13200, Modification M071", and 
4. "Hanford Federal Facility Agreement and Consent Order" (Tri-Party Agreement), Revision 5, DOE/RL-89-10.

Mission requirements are maintained under configuration control in the Hanford Site Technical Database (HSTD), and described in this section. The assigned requirement identifier, used in the HSTD, is provided in parenthesis following the requirement, where applicable.

\section{"Hanford Site Environmental Management Specification", (HSEMS) DOE/RL-97-55}

This specification is the source of primary requirements for the project work scope definition. Project completion will be attained through satisfying the technical requirements contained in the HSEMS. Requirements include verbatim requirements, as well as interpreted requirements resulting from resolution of requirement duplication, conflicts, or ambiguity.

- The SNF Project will transfer secondary waste streams generated by project activities (such as solid low-level waste (LLW), transuranic (TRU) solid waste, and liquid effluents) for storage or disposal on the Hanford Site. (WM01-12 NUMBER. HSS.4.2.3.3.i)

- Reactors on the River facilities shall be transitioned to a low cost, stable, deactivated condition. (Facility, Transition 1.RR NUMBER. SFA.C.RR.F.3)

- $100 \mathrm{~K}$ Area Facilities shall be stabilized and cleaned sufficient to transition to D\&D. (Facility, Transition 1.RR.K Basins NUMBER. SFA.C.RR.F.6)

- Accomplish fuel conditioning in accordance with project plans, which currently include a cold-vacuum drying (CVD) process, located in the $100 \mathrm{~K}$ area. During fiscal year (FY) 1996, process parameters to support design will be defined, the design contract will be awarded, and design activities will be initiated. Construct the CVD Facility and make it available for fuel transfer. Transfer the facility(s) to the Environmental Restoration Project for D\&D on completion of operations. (SNF, Treat.1.RR.K Basins.1 NUMBER. SFA.T.RR.M.3)

- Debris shall be removed from the $100 \mathrm{~K}$ Area Facilities. (Waste, Retrieve.RR.Debris.K Basins NUMBER. SFA.C.RR.W.2)

- Contaminated equipment shall be removed from the $100 \mathrm{~K}$ Area Facilities. (Waste, Retrieve.RR.Equipment.K Basins NUMBER. SFA.C.RR.W.3)

- Water contained in the $100 \mathrm{~K}$ Area Facilities shall be treated to maintain water quality and safe conditions within the basins and to reduce tritium levels. (Waste, Treat.RR.K Basin.Water NUMBER. SFA.T.RR.W.1) 
SNF-4961, Rev. 0

- Remove fuel, sludge, associated equipment, and debris from the K Basins. (Nuclear Material, Retrieve 1.RR.K Basin.1 NUMBER. PHMC.C.3.C.2.a)

- Remove sludge and debris from the K Basins for disposition with other Hanford Site wastes and materials. (WM01-20 NUMBER. HSS.4.2.3.5.1.d)

- Sludge (50 to $70 \mathrm{~m} 3 \mathrm{max}$.) shall be removed from the K Basins. Sludge shall be considered SNF until it has been removed from the K Basins. Sludge that is removed from the $\mathrm{K}$ Basins by a sludge retrieval process shall be handled as RH TRU mixed waste after removal from the basins. (Waste, Retrieve.RR.Sludge.K Basins NUMBER. SFA.C.RR.W.1)

\section{DOE/RL-96-92, Hanford Strategic Plan}

- Remove and/or stabilize fuel, surplus facilities, and waste sites to protect groundwater and the Columbia River and to ensure protection of people, the environment, and natural/cultural resources. Pending Congressional action on the Wild and Scenic River designation, use will continue to be restricted, sensitive ecological, cultural, and Native American resources will be protected.

- Safe, suitable, secure onsite storage will be provided for all nuclear materials pending decisions on final disposition or until beneficial offsite uses are identified. Facilities without identified future uses will be transitioned to low-cost, stable deactivated conditions (requiring minimal surveillance and maintenance) pending eventual D\&D and removal or closure.

- Surplus facilities will be decommissioned and decontaminated sufficiently to enable removal or closure through entombment.

\section{DOE/RL-89-10, Hanford Federal Facility Agreement and Consent Order (Tri-Party Agreement), Revision 5}

The Tri-Party Agreement (TPA) requirements applicable to the Transition project are taken from federal Facility Agreement and Consent Order Change Control Form, Change Number M-34-98-01A, September 2, 1998.

M-34-00A Complete removal of spent nuclear fuel, sludge, debris, and water at DOEs K Basins. (Due Date 07-30-2007) 
M-34-04 The DOE shall submit a remedial design report/remedial action work plan for the K Basins interim action to the U.S. Environmental Protection Agency (EPA) and the U.S. Department of Ecology (Ecology) for approval. This work plan shall be constrained by these (M-34-98-01A) agreement milestones and target dates, and shall propose detailed schedules for initiating and completing activities required for the removal of hazardous substances for K Basins (SNF, sludge, debris, and water). (Due Date 03-31-2000)

M-34-05-T01 Submit DOE approved annual report on quantities, character, and management (e.g., segregation and management subsequent to removal) of $\mathrm{K}$ Basins debris to Ecology and EPA. The final report of this series shall be the one occurring one year after completion of milestone M-34-00A. (Due date annually)

M-34-07-T01 Complete final safety basis for the transfer of $\mathrm{K}$ Basins sludge. (Due Date $12 / 31 / 2003)$

Provide to Ecology and EPA the DOE approved: 1) K Basin Safety Analysis Report (SAR) update; 2) storage facility SAR or SAR modification; and, 3) SARP authorizing the transfer to K Basins sludge.

M-34-08 Initiate full-scale K East Basin sludge removal. (Due Date 07-31-2004)

M-34-09-T01 Complete K Basins rack and canister removal. (Due Date 12-31-2004)

M-34-10 Complete sludge removal from K Basins. (Due Date 08-31-2005)

M-34-19 Initiate removal, replacement, and treatment of contaminated K Basins water where tritium concentrations exceed $300,000 \mathrm{pCi} / \mathrm{L}$. (Due Date 04-30-2004)

M-34-20 Complete removal, replacement, and treatment of contaminated $\mathrm{K}$ Basins water such that the tritium concentration in the basin is decreased and is maintained at or below $300,000 \mathrm{pCi} / \mathrm{L}$. This milestone could be satisfied by removing all water. (Due Date 10-31-2005)

M-34-21 Initiate full-scale K West Basin Water removal. (Due Date 09-30-2004)

M-34-22 Complete K West Basin water removal. (Due Date 09-30-2005)

M-34-23 Initiate full scale K East Basin water removal. (Due Date 10-31-2005)

M-34-24 Complete K East Basin water removal. (Due Date 10-31-2006) 
SNF-4961, Rev. 0

\subsection{AUTHORIZATION BASIS, NEPA, AND PERMITS}

The Transition Project will manage all activities in accordance with approved Authorization Basis documents and approved Standards Requirements Identification Documents (S/RID).

- "K Basin Safety Analysis Report", WHC-SD-SNF-WM-062, including "K Basin Hazard Categorization", WHC-SD-SNF-HC-001, and any approved amendments thereto.

- "K Basins Technical Safety Requirements", WHC-SD-SNF-TSR-001, and any approved amendments thereto.

- Letter J. D. Wagoner, RL, to R. D. Hanson, Acting President, FDH, Contract No. DE-AC06-96RL13200-K Basins SAR Annual Update, and attached Safety Evaluation Report (SER), dated September 18, 1998. (98-SFD-176).

- Letter J. D. Wagoner, RL, to R. D. Hanson, Acting President, FDH, Contract No. DE-AC06-96RL13200-K Basins SAR. WHC-SD-WM-SAR-062, proposed Revision 3F, and K Basins Technical Safety Requirements (TSR) WHC-SD-SNF-TSR-001, proposed revision 0-D, Drain Valve Unreviewed Safety Question (USQ) and Justification for Continued Operation (JCO), and attached SER, dated September 18, 1998 (98-SFD-187), Page Change K 05/26/1999.

- HNF-SD-SNF-SAR-002, SNF Project CVD Facility SAR and any approved amendments thereto.

The Transition Project activities are subject to National Environmental Policy Act (NEPA) and shall comply with the NEPA Record of Decision (ROD) and equivalent Comprehensive Environmental Response, Compensation and Liability Act of 1980 (CERCLA) requirements. The following NEPA documents apply:

- SNF K Basins Project Environmental Impact Statement ROD (3-96).

- Environmental Permits obtained in the name of RL or Fluor Hanford (FH) that include provisions applicable to SNF K Basins Project facilities and/or operations, including, but not limited to permits issued under the authority of the resource Conservation and recovery Act, as amended; the Federal Water Pollution Control Act (Clean Water Act) as amended; the Toxic Substances Control Act, as amended; and the Clean Air Act, as amended.

- CERCLA documents and RODs that contain requirements applicable to SNF K Basins Project facilities and/or operations. 
SNF-4961, Rev. 0

- Resource Conservation and Recovery Act and Safe Drinking Water Act documents that contain requirements applicable to SNF K Basins Project facilities and/or operations.

- Voluntary compliance letters, notices of correction, notices of noncompliance, notices of violation, notices of penalty, administrative or consent orders, or other legal documents issued by an authorized agency delegated regulatory authority that contain requirements applicable to SNF Basins Project facilities and/or operations, including subsequent approved revisions to referenced documents.

\subsection{REQUIREMENT SOURCES}

The following requirement sources are applicable to the operating functions. These sources were derived from Contract Modification M071, Updated Appendix C, DOE Directives.

In addition to the mission requirements, the Transition Project will comply with the requirements of applicable Federal, state, and local laws and regulations. These laws and regulations are identified in:

a) DOE/RL-97-55 , "Hanford Site Environmental Management Specification”, (DOE/RL),

b) Contract No. DE-AC06-96RL13200, Modification M071, and

c) WHC-SD-SNF-SD-005, "Spent Nuclear Fuel Project Technical Baseline Description Fiscal Year 1996” (WHC 1996b).

These sources are applicable to work and activities conducted/accomplished by FH.

Environmental, Safety and Health requirements are included. 


\subsection{ARCHITECTURE}

This section provides an architectural description, also known as the baseline concept description, of the transition Project and its sub-elements. The Transition Project consists of subprojects associated with the removal and transferring to disposition $\mathrm{K}$ Basin materials, and processes for stabilizing facilities, systems, and equipment.

Table 5-1 provides a description of the provisions, process, or strategy for removing water, sludge, and debris materials, Stabilizing Equipment and Systems Stabilizing Facilities, Managing Effluents and Wastes, and Transferring K Basin Facilities to ER.

\subsection{SPENT NUCLEAR FUEL PROJECT TRANSITION ARCHITECTURE}

A Facilities Transition Strategy Document (FTSD) is in preparation that will summarize the scope of work to be completed during facility transition, deactivation tasks to be performed, technical approaches for conducting the work, necessary modifications to the current safety/authorization basis, turnover documentation to be developed, environmental permitting status, current commitments and action items, safety and health assessments, a project schedule, and resource plan. The FTSD includes (in outline form) deactivation work plans for all SNF facilities in $100 \mathrm{~K}$ Area. The FTSD identifies turnover commitments negotiated in a Memorandum of Understanding (MOU) between the SNF and ER Projects.

T.1 - Provisions, Process, or Strategy for removing water, sludge, and debris materials.

\section{T.1.1 Provisions for water removal system -}

The existing IWTS will be utilized to pump water from the basin through the Ion Exchange Modules (IXMs) into tanker trucks. Provision will be provided to connect the IWTS piping to the tanker truck. Shipments of water will be sampled and analyzed and sent for off-loading to either the 200 Area ETF or the LERF as directed by the WPD. Once the tanker is offloaded it will be flushed and rinsed, if required.

\section{T.1.2 Provisions for sludge removal system -}

Provisions for collecting sludge from the $105 \mathrm{KE} / \mathrm{KW}$ basin floors, pits, IWTS knock-out pots and settler tanks and place it in a temporary storage area within the facility. Provisions for pumping sludge to a loadout system for transfer to a transport container. Provisions for moving the transport container to T Plant for interim storage pending final disposition. The following systems and equipment will be acquired to support sludge removal:

- Floor sludge retrieval system

- Sludge loadout system

- Sludge handling and transport system 
SNF-4961, Rev. 0

- T Plant off-loading equipment

T.1.3 Provisions for debris removal system -

Provisions for (1) rack removal; (2) removal of fuel handling equipment; and (3) removal of water treatment and sludge removal equipment. These equipment items will be retrieved, size reduced (as necessary), pressure-washed, and packaged in burial boxes for disposal at the Environmental Restoration Disposal Facility (ERDF). The following systems and equipment will be acquired to support debris removal:

- Retrieval equipment

- Pressure-washing equipment/station

- Size reduction equipment

- Lifting apparatus

T.2 - Provisions, process, or strategy description for Stabilizing Equipment and Systems.

Includes provisions for draining, disconnecting, blanking-off, locking and tagging utility connections (i.e., electrical power, potable water, sewer, communications lines) out of service; documentation of zero energy checks for all electrical and mechanical systems; provisions for downgrading fire protection systems consistent with Surveillance and Maintenance (S\&M) requirements; provisions for placing essential equipment (e.g., elevators, cranes) that would be used later in decommissioning into a safe lay-up condition. Provides documentation for structures, systems, and components (SSCs) designated in the facility safety/authorization basis regarding status at turnover (e.g., deactivated or operational), configuration, and any specific $S \& M$ requirements.

\section{T.3 - Provisions, process, or strategy description for Stabilizing Facilities.}

Turnover documentation will be prepared regarding (1) safety and authorization basis for S\&M mission, (2) status of facility permits, (3) Fire Hazards Analysis, (4) inventory of any hazardous materials remaining in facilities at turnover, (5) final Radiological

Surveys, (6) Asbestos Surveys, (7) Confined Space Audits (if applicable), and (8) facility S\&M Plans. For the $105 \mathrm{KE}$ and $\mathrm{KW}$ Basins, the existing safety and authorization basis will be modified to reflect the completion of fuel removal from the basins, the mission change to cleanout and deactivation, the nature of specific activities associated with the new mission, and potential accident, exposure, and release scenarios associated with the work and the residual inventory. For other (radiological and non-nuclear) facilities, new safety documentation will be prepared to revise the authorization basis for deactivation work. Includes provisions for appropriate lighting, vector controls, physical access controls and surveillance systems. 
T.4 - Provisions, process, or strategy description for Managing Effluents and Wastes.

Provisions for removing regulated solid wastes (e.g., radiological waste, dangerous waste and asbestos) including characterizing, placing waste in suitable containers for disposal, labeling containers, provisions for managing storage (control and monitoring) on site in designated storage area(s), provisions for manifesting and transportation of waste shipments, and provisions for disposal in appropriate on-site and off-site disposal facilities.

T.5 - Provisions, process, or strategy description for Transferring K Basin Facilities to ER.

An MOU has been negotiated between the SNF Project and the ER Project delineating roles and responsibilities, acceptance criteria, and a target completion date (2007) for transitioning of SNF facilities in the $100 \mathrm{~K}$ Area to the ER Project. 


\subsection{INTERFACES}

Interfaces are a component of the Transition project Technical Baseline and as such are maintained under configuration control. Interfaces bound the scope of the project and contain requirements of those boundaries. Interfaces are identified in the early project stages and continue to be identified and developed throughout the project life cycle. The Transition Project identifies, documents, and controls interfaces in accordance with AP EN-6-021, "Interface Control Process".

The Transition Project interfaces with other Hanford Site programs associated with the transfer of $100 \mathrm{~K}$ Area Facilities to the organization responsible for final disposition, ER. The Transition Project also interfaces with other Hanford Site facilities (T Plant, ETF or LERF) associated with the disposition of $100 \mathrm{~K}$ Area Facility materials, such as water, sludge, and debris. The Transition Project interfaces with SNF Project infrastructure and utilities, e.g., electric power and water. The interfaces with other SNF Project elements (sub-projects) include the Fuel Retrieval Subproject, Multi-Canister Overpack Subproject, and IWTS.

The Transition Project interface description is shown in Table 6-1.

Table 6-1. Transition Project Interface Description

\begin{tabular}{|c|l|}
\hline $\begin{array}{c}\text { Interface } \\
\text { Control } \\
\text { Number }\end{array}$ & \multicolumn{1}{|c|}{ Interface Description } \\
\hline X-72 & $\begin{array}{l}\text { MOU between the SNF Project (Project Hanford Management Contract) and } \\
\text { Bechtel Hanford Incorporated }\end{array}$ \\
\hline X-15 & $\begin{array}{l}\text { POU, Disposition and Transport of Water from 100 K Basins to the 200 Area ETF } \\
\text { Project, Interim Storage of K Basins Sludge in T Plant }\end{array}$ \\
\hline X-73 & $\begin{array}{l}\text { Memorandum of Agreement between the Assistant Manager for Waste Management } \\
\text { SNF Project Division (AMW/SFD), and the Assistant Manager for Facility } \\
\text { Transition, Transition Program Division (AMF/TPD), and the Assistant Manager for } \\
\text { ER, Restoration Projects (AME/RPD) on the Transition of Management } \\
\text { Responsibility for the 100-K Basins Facilities, December 5, 1997 }\end{array}$ \\
\hline X-70 & $\begin{array}{l}\text { MOU between the Waste Programs Division, Office of the Assistant Manager for } \\
\text { Waste Management, and the SNF Project Division, Office of the Assistant Manager } \\
\text { for Waste Management on the 1706KE Transfer from Analytical Services to SNF } \\
\text { Project Division, July 22, 1996 }\end{array}$ \\
\hline 023 & $\begin{array}{l}\text { "Interface Control Document between the Spent Nuclear Fuel Project and Solid } \\
\text { Waste Disposal Division", WHC-SD-WM-PICD-009, Revision 0 }\end{array}$ \\
\hline 025 & KE Basin Debris Low-Level Solid Waste to KE Basin Solid Waste Handling \\
\hline 026 & Oversize Fuel/Debris Pieces from KE Basin Sludge Retrieval-(Floor), 1/4" Screening \\
\hline 027 & Excess KE Basin Sludge Retrieval Water \\
\hline 028 & Oversize Fuel/Debris Pieces from KE Basin (Floor \& Processing) 1/4" Screening \\
\hline 029 & KE Basin Sludge Process Control Batch Samples \\
\hline
\end{tabular}




\begin{tabular}{|l|l|}
\hline 032 & KW Basin Sludge Process Control Batch Samples \\
\hline 040 & $\begin{array}{l}\text { Solid Waste Path out of KE \& KW Basins in Support of Debris Removal Sub- } \\
\text { Project Activities }\end{array}$ \\
\hline 041 & $\begin{array}{l}\text { Clear, Decontaminated, Deionized Water from KE Water Treatment to Debris } \\
\text { Removals High Pressure Cleaning Pumps }\end{array}$ \\
\hline 042 & $\begin{array}{l}\text { Clear, Decontaminated, Deionized Water from KW Water Treatment to Debris } \\
\text { Removals High Pressure Cleaning Pumps }\end{array}$ \\
\hline 051 & $\begin{array}{l}\text { Contamination Control Water KW Debris Removals Canister Cleaning Enclosure to } \\
\text { KW Water Treatment }\end{array}$ \\
\hline 052 & KE Sludge Loading Transfer Line Flush Water Supply \\
\hline 053 & KW Sludge Loading Transfer Line Flush Water Supply \\
\hline 054 & KE Basin Sludge Transport Loading Exhaust \\
\hline 055 & KW Basin Sludge Transport Loading Exhaust \\
\hline 064 & KE Basin Sludge Loading from Weasel Pit \\
\hline 065 & KW Sludge Loading and Flush Water Return \\
\hline 097 & $\begin{array}{l}\text { KE Basin Debris TRU Solid Waste, to KE Solid Waste Handling, Packaged as Solid } \\
\text { Waste }\end{array}$ \\
\hline 098 & $\begin{array}{l}\text { KE Basin Debris Mixed TRU Solid Waste, to KE Solid Waste Handling, Packaged } \\
\text { as Solid Waste }\end{array}$ \\
\hline 099 & KW Basin TRU Solid Waste to K Basin Solid Waste Handling \\
\hline 126 & Empty Scrap Holders to KE Sludge Removal \\
\hline 128 & Empty Scrap Holders to KW Sludge Removal \\
\hline 156 & Electrical Power \\
\hline 166 & High Pressure Pump \\
\hline 176 & $\begin{array}{l}\text { Clear Decontaminated Water from KE Water Treatment to Debris Removal Canister } \\
\text { Loadout Area }\end{array}$ \\
\hline 177 & $\begin{array}{l}\text { Clear Decontaminated Water from KW Water Treatment to Debris Removal } \\
\text { Canister Loadout Area }\end{array}$ \\
\hline 180 & Retrieved KE Basin Sludge - Sludge Removal to KE Water Treatment \\
\hline 182 & KE Debris Mixed LLW to K Basin Solid Waste handling \\
\hline 183 & KE Debris Mixed Toxic Solid Waste to K Basin Solid Waste Handling \\
\hline 204 & KW Basin Sludge Transfer from Settler tanks \& Knockout Pots \\
\hline 209 & $\begin{array}{l}\text { Clear, Decontaminated Deionized Water from KE Water Treatment to Debris } \\
\text { Removal Aqua Blaster Cleaning Pump }\end{array}$ \\
\hline
\end{tabular}


SNF-4961, Rev. 0

\section{$7.0 \quad$ ISSUES}

Issues, which have a potential to impact technical, cost, and schedule baselines, are identified below. These issues need resolution in order to achieve project success. Enabling assumptions may be needed depending on the status of the open issue and project status. Issues will be linked to appropriate project functions to identify ownership and enable project impact quantification.

Table 7-1. Transition Project Issues

\begin{tabular}{|c|c|c|c|}
\hline $\begin{array}{c}\text { Issue } \\
\text { Identification }\end{array}$ & Issue Description & $\begin{array}{l}\text { Enabling } \\
\text { Assumption }\end{array}$ & $\begin{array}{l}\text { Assigned } \\
\text { Function }\end{array}$ \\
\hline I-1 & $\begin{array}{l}\text { End Point Criteria is not finalized. These criteria need } \\
\text { to be defined in order to achieve Project success. } \\
\text { Facility checklists have been received. Additional } \\
\text { criteria may be imposed by RL, regulators, tribes, and } \\
\text { the public. }\end{array}$ & & tsd 2.1.4.2.1.1.1 \\
\hline $\mathrm{I}-2$ & $\begin{array}{l}\text { The technical, cost, and schedule baselines cannot be } \\
\text { accurately established until the facility, systems, and } \\
\text { equipment cleanliness is determined. }\end{array}$ & & tsd 2.1.4.2.1.1 \\
\hline $\mathrm{I}-3$ & $\begin{array}{l}\text { Waste classification is unknown and impacts technical, } \\
\text { cost, and schedule baseline development. }\end{array}$ & & $\begin{array}{l}\text { tsd 2.1.4.2.1.2.6, } \\
\text { tsd 2.1.4.2.1.3.3 }\end{array}$ \\
\hline $\mathrm{I}-4$ & $\begin{array}{l}\text { Will T Plant be upgraded to meet regulatory } \\
\text { requirements? }\end{array}$ & EA-6 & tsd 2.1.4.2.1.1.4 \\
\hline $\mathrm{I}-5$ & Turnover contamination criteria are undefined. & & tsd 2.1.4.2.1.1.1 \\
\hline $\mathrm{I}-6$ & $\begin{array}{l}\text { The amount of debris remaining in the cooling pools is } \\
\text { undefined. }\end{array}$ & EA-2 & tsd 2.1.4.2.1.1.1.4 \\
\hline $\mathrm{I}-7$. & $\begin{array}{l}\text { The extent of facility decontamination is unknown and } \\
\text { impacts the technical, cost, and schedule baselines. }\end{array}$ & EA-1 & $\begin{array}{l}\text { tsd 2.1.4.2.1.2.5, } \\
\text { tsd 2.1.4.2.1.3.2 }\end{array}$ \\
\hline $\mathrm{I}-8$ & T Plant sludge acceptance criteria is undefined. & $\begin{array}{c}\text { EA-3, EA-4, } \\
\text { EA-5 }\end{array}$ & $\begin{array}{l}\text { tsd 2.1.4.2.1.1.4, } \\
\text { tsd 2.1.4.2.1.2.2 }\end{array}$ \\
\hline $\mathrm{I}-9$ & $\begin{array}{l}\text { No detailed cost estimate has been done to validate that } \\
\text { the transport and storage of waste in T Plant is cost } \\
\text { effective. }\end{array}$ & & $\begin{array}{l}\text { tsd 2.1.4.2.1.1.4, } \\
\text { tsd 2.1.4.2.1.2.2 }\end{array}$ \\
\hline $\mathrm{I}-10$ & $\begin{array}{l}\text { Environmental, Safety \& Health requirements for } 100 \mathrm{~K} \\
\text { Area facilities are undefined. }\end{array}$ & & tsd 2.1.4.2.1 \\
\hline $\mathrm{I}-11$ & $\begin{array}{l}\text { SNF fines }(\leq 1 / 4 \text { ") contained within sludge could result in } \\
\text { additional criticality requirements. }\end{array}$ & $\begin{array}{l}\text { EA-7, EA-8, } \\
\text { EA-9 }\end{array}$ & $\begin{array}{l}\text { tsd 2.1.4.2.1.1.4, } \\
\text { tsd 2.1.4.2.1.2.2 }\end{array}$ \\
\hline $\mathrm{I}-12$ & $\begin{array}{l}\text { Hanford Remedial Action Environmental Impact } \\
\text { Statement and Comprehensive Land Use Plan", } \\
\text { DOE/EIS-0222D, requires basin water to be treated to } \\
\text { reduce tritium levels. However, the project will be } \\
\text { draining practically all of the water out of the basins } \\
\text { making treatment unnecessary. }\end{array}$ & EA-11 & tsd 2.1.4.2.1 \\
\hline
\end{tabular}




\subsection{ENABLING ASSUMPTIONS}

This section identifies assumptions made to enable project progress. These assumptions will need validation. Enabling Assumptions are linked to project issues and trade studies, as appropriate. Trade studies may be used to support assumption validation. Transition Project Enabling Assumptions are identified in Table 8-1.

Table 8-1. Transition Project Enabling Assumptions

\begin{tabular}{|c|c|c|c|}
\hline $\begin{array}{c}\text { Assumption } \\
\text { Identification }\end{array}$ & Enabling Assumption Description & Issue & $\begin{array}{l}\text { Assigned } \\
\text { Function }\end{array}$ \\
\hline EA-1 & $\begin{array}{l}\text { Will be able to decontaminate walls to a low enough } \\
\text { level to maintain a dry condition or provide adequate } \\
\text { shielding for the basins to enable access by personnel. }\end{array}$ & $\mathrm{I}-7$ & $\begin{array}{l}\text { tsd } 2.1 .4 .2 .1 .2 .5 \\
\text { tsd } 2 \cdot 1 \cdot 4.2 .1 .3 .2\end{array}$ \\
\hline EA-2 & $\begin{array}{l}\text { All debris canisters will be out of the Basin cooling } \\
\text { pools in parallel with fuel retrieval. }\end{array}$ & $\mathrm{I}-6$ & tsd 2.1.4.2.1.1.1.4 \\
\hline EA-3 & $\begin{array}{l}\text { No pretreatment of the sludge is required prior to } \\
\text { shipment to T Plant. }\end{array}$ & $\mathrm{I}-8$ & $\begin{array}{l}\text { tsd } .2 .1 .4 .2 .1 .1 .4 \\
\text { tsd.2.1.4.2.1.2.2 }\end{array}$ \\
\hline EA-4 & $\begin{array}{l}\text { Floor and pit sludge can be stored at T Plant in a dry } \\
\text { fashion (either on the canyon deck or in a process cell). }\end{array}$ & $\mathrm{I}-8$ & $\begin{array}{l}\text { tsd } .2 .1 \cdot 4.2 .1 .1 .4 \\
\text { tsd.2.1.4.2.1.2.2 }\end{array}$ \\
\hline$\overline{E A-5}$ & $\begin{array}{l}\text { Fuel wash and canister sludge can be stored in the } \\
\text { existing T Plant pool. }\end{array}$ & $\mathrm{I}-8$ & $\begin{array}{l}\text { tsd } .2 .1 .4 .2 .1 .1 .4 \\
\text { tsd.2.1.4.2.1.2.2 }\end{array}$ \\
\hline EA-6 & $\begin{array}{l}\text { Actions can be taken to avoid extreme cost impacts due } \\
\text { to upgrades at T Plant (i.e., upgrades to meet seismic } \\
\text { qualifications, Resource Conservation and Recovery } \\
\text { Act (RCRA) compliance, safeguards). }\end{array}$ & $\mathrm{I}-4$ & tsd.2.1.4.2.1.1.4 \\
\hline EA-7 & $\begin{array}{l}\text { Floor and pit sludge will exit the Basins as waste and } \\
\text { will not be subject to safeguards. }\end{array}$ & $\mathrm{I}-11$ & $\begin{array}{l}\text { tsd.2.1.4.2.1.1.4 } \\
\text { tsd2.1.4.2.1.2.2 }\end{array}$ \\
\hline EA-8 & There are no criticality issues with floor and pit sludge. & $\mathrm{I}-11$ & $\begin{array}{l}\text { tsd.2.1.4.2.1.1.4, } \\
\text { tsd2.1.4.2.1.2.2 }\end{array}$ \\
\hline$\overline{\text { EA-9 }}$ & $\begin{array}{l}\text { Canister and fuel wash sludge will require criticality } \\
\text { safe containers, storage and handling. }\end{array}$ & $\mathrm{I}-11$ & $\begin{array}{l}\text { tsd.2.1.4.2.1.1.4, } \\
\text { tsd2.1.4.2.1.2.2 }\end{array}$ \\
\hline EA-10 & Pyrophoric sludge will be stored underwater. & $\mathrm{I}-8, \mathrm{I}-9$ & $\begin{array}{l}\text { tsd 2.1.4.2.1.1.4, } \\
\text { tsd 2.1.4.2.1.2.2 }\end{array}$ \\
\hline EA-11 & $\begin{array}{l}\text { K Basin water will not be treated to reduce tritium } \\
\text { levels. }\end{array}$ & $\mathrm{I}-12$ & tsd 2.1.4.2.1 \\
\hline
\end{tabular}


SNF-4961, Rev. 0

\section{$9.0 \quad$ STUDIES}

The enabling assumptions listed above will be addressed/validated during the planned pre-conceptual/conceptual studies of the sludge handling work to be prepared through the end of FY 00 . 
SNF-4961, Rev. 0

\subsection{REFERENCES}

This section describes references used within the document text.

Baseline Change Request, SNF-1998-015, K Basin Transition Work Scope Transfer to SNF, January 20, 1998.

Baseline Change Request, PK1-1999-002, SNF WBS Change for Transition Project, July $16,1999$.

Brisbin, S. A., Pearce, K. L., 1996, WHC-SD-WM-FDC-052, Revision 0, Functional Design Criteria for Sludge Receiving Station, Westinghouse Hanford Company, Richland, Washington.

Contract No. DE-AC06-96RL13200, Modification M071.

Crystal, J. B., WHC-SD-SNF-FRD-018, Revision 0, 1995, Functions and Requirements for Debris Removal from 105 KE Basin South Loadout Pit, Westinghouse Hanford Company, Richland, Washington.

DOE/RL-89-10, Hanford Federal Facility Agreement and Consent Order (Tri-Party Agreement), Revision 5.

DOE/RL, 1999, Hanford Site Environmental Management Specification, DOE/RL-97-55.

FDH, 1998a, HNF-SP-1104, Spent Fuels Multi-Year Work Plan.

FDH, 1998b, HNF-3552, Spent Nuclear Fuel Project Execution Plan.

Hanford Remedial Action Environmental Impact Statement and Comprehensive Land Use Plan, DOE/EIS-0222D.

Hanford Site Environmental Management Specification, DOE/RL-97-55.

Huisingh, J. S., HNF-SD-SNF-FRD-021, Revision 1, 1997, Functions and Requirements for the Dummy Elevator Pit Debris Removal Project at the 105KE Basin, Westinghouse Hanford Company, Richland, Washington.

Precechtel, D. R., 1996, WHC-SD-SNF-FDC-006, Revision 1, Functional Design Criteria for the K Basins Sludge Process and Loadout System, Westinghouse Hanford Company, Richland, Washington.

Precechtel, D. R., 1998, HNF-SD-SNF-FDC-004, Revision 1, Functional Design Criteria for the K Basins Sludge Removal System, Duke Engineering \& Services, Hanford, Inc, Richland, Washington. 
Precechtel, D. R., 1998, HNF-SD-SNF-FDC-005, Revision 1, Functional Design Criteria for the K Basins Sludge Retrieval System, Westinghouse Hanford Company, Richland, Washington.

Spent Nuclear Fuel Project, Administrative Procedure EN-6-021, Interface Control Process, Revision 0, July 1, 1999.

Tomaszewski, T. A., WHC-SD-TP-PDC-035, Revision 0, 1996, Packaging Design Criteria for the K East Basin Sludge Transportation System, Westinghouse Hanford Company, Richland, Washington.

WHC, 1995a, WHC-IP-1117, Revision 0, Hanford Site Systems Engineering Manual, Westinghouse Hanford Company, Richland, Washington.

WHC, 1995b, SEP-3.0, System Function Definition, Revision 0, Hanford Site Systems Engineering Manual, Westinghouse Hanford Company, Richland, Washington.

WHC, 1995c, SEP-4.0, Requirements Identification \& Allocation, Revision 0, Hanford Site Systems Engineering Manual, Westinghouse Hanford Company, Richland, Washington.

WHC, 1996a, WHC-SD-SNF-SEMP-001, Revision 1, Spent Nuclear Fuel Project, Systems Engineering Management Plan, Westinghouse Hanford Company, Richland, Washington.

WHC, 1996b, WHC-SD-SNF-SD-005, Revision 1, Spent Nuclear Fuel Project Technical Baseline Document, Westinghouse Hanford Company, Richland, Washington.

Yanochko, R. M., 1997, WHC-SD-SNF-FRD-009, Revision 0, Functions \& Requirements for Debris Removal Subproject, Westinghouse Hanford Company, Richland, Washington. 


\section{DISTRIBUTION SHEET}

To

Distribution

Project Title/Work Order

Transition Project

\section{Name}

D. E. Bullock

C. C. Farwick

G. D. Forehand

O. M. Holgado

L. B. McDaniel

R. S. MCBeath

F. J. Muller

W. C. Miller

M. F. NiCol

J. B. Payne

S. H. Peck

C. A. Petersen

D. R. Precechtel

R. W. Rasmussen

W. W. Rutherford

A. E. Smith

D. W. Smith

D. H. Splett

R. M. Suyama

J. E. Turnbaugh

D. J. Watson

R. M. Yanochko

SNF Project Procedures

SNF Project Training

SNF Project File

From

Systems Engineering



